\title{
Iron chelation by curcumin suppress both curcumin-induced autoghagy and cell death together with iron overload neoplastic transformation
}

\author{
Nathan E. Rainey ${ }^{1-2 *}$, Aoula Moustapha ${ }^{1 *}$, Ana Saric ${ }^{3}$, Gael Nicolas ${ }^{4}$, Franck Sureau ${ }^{5}$, and Patrice X. Petit ${ }^{1 凶}$ \\ ${ }^{1}$ SPPIN - Saints Pères Paris Institute for the Neurosciences, UMR8003 CNRS, 45 rue des Saint-Pères, 75006 Paris, France \\ ${ }^{2}$ LVTS - Laboratory for Vascular Translational Science, UMR1148 INSERM, Université Paris XIII, Sorbonne Paris Cité, F-93017 Bobigny, France \\ ${ }^{3}$ Division of Molecular Medicine, Ruder Boškovic Institute, Bijenička cesta 54, 10000 Zagreb, Croatia \\ ${ }^{4} \mathrm{CRI}$ - Centre de recherche sur l'inflammation, UMR1149/ERL8252 CNRS, Université Paris Diderot, faculté de médecine, 16 rue Henri Huchard, F-75018 Paris. France \\ ${ }^{5}$ LJP - Laboratoire Jean Perrin, UMR8237 CNRS, Université Pierre et Marie Curie, FRE 3231 Case Courrier 138, 4 place Jussieu, 75252 Paris cedex 05 \\ ${ }^{*}$ These authors contributed equally.
}

Iron overload, notably caused by hereditary hemochromatosis, is an excess storage of iron in various organs which cause tissue damage and may promote tumorigenesis. To manage that disorder, free iron depletion can be induced by iron chelators like deferoxamine which are gaining interest also in the cancer field since iron stock could be a potent target for managing tumorigenesis. Curcumin, a well-known active substance extracted from the turmeric rhizome, has shown to be destabilizing endoplasmic reticulum and secondarily lysozomes, increasing mitophagy/autophagy and subsequent apoptosis. Recent findings show that cells treated with curcumin exhibit also a decrease in ferritin, which is consistent with it's chemical structure and iron chelating activity. Here we investigated how curcumin would play on the intracellular effects of iron overload via FeNitriloacetic acid or Ferric ammonium citrate loading in Huh-7 cells and explore consequences in terms of antioxidant activity, autophagy, or apoptotic signal transduction. With T51B and RL-34 epithelial cells experiments, we brought evidence that curcumin-iron complexation abolishes both curcumin-induced autophagy and apoptosis together with the tumorigenic action of iron overload.

Apoptosis | Autophagy | Cell death | Chelation | Curcumin | Endoplasmic reticulum | Ferroptosis | Iron | Mitochondria | Superoxide anions | Stress

Correspondence: patrice.petit@inserm.fr \& nathan.rainey@inserm.fr

Introduction. Iron is a key element of numerous biological processes but the presence of free or loosely bound iron can be toxic to the cell (1). Iron being an active redox metal, the excess free form can generate reactive oxygen species through Haber-Weiss reduction followed by Fenton reaction $(2,3)$. Liver plays a major role in regulating iron storage in case of excess or deficiency in the blood pool. Aberrant iron accumulation can lead to cirrhosis and hepatocarcinoma but also heart damage, joint and metabolic disorders $(4,5)$. Phlebotomy remains the mainstay of ironoverload diseases but iron chelation therapy has proven to be a valuable alternative(6). Although iron chelation therapy was initially designed to alleviates toxic effect of excess iron occuring in iron-overload diseases, the novel toxicological properties of somes iron chelators complexes have radically shifted their intended applications toward cancer chemother-<smiles></smiles><smiles>COc1cc(/C=C/C2=CC(/C=C/c3ccc(O)c(OC)c3)OC(C)(C(F)(F)Cl)O2)ccc1O</smiles>

Fig. 1. Curcumin chelates metals. Schematic representation of the curcumin chelation towards bivalent metals| a. Curcumin chelates can adopt a 2:1 configuration | b. Curcumin can also chelates metals in conjunction with other ligands

apy (7-9). Some iron chelators are able not only to bind but also inhibit the redox properties of free labile iron. Such ligands may prevent iron from participating in Fenton reaction, inhibiting the formation of reactive oxygen species (ROS) like hydroxyl radical which initiates oxidative damages (10) and also ferroptosis, recently recognized as a form of regulated necrotic cell death (11). Ferroptosis is usually designed as one of the multiple variant of cell death than can be characterized by high intracellular level of free iron associated with ROS $(12,13)$. Ferroptosis is linked to the production of reduced glutathion and/or to the alterations of glutathion peroxidase 4 (GPX4) which usually acts as ROS controllers 
(14-16). Additives markers of ferroptosis are lipid peroxidation and protein carbonylation leading to more ROS and death signaling $(10,17)$. Interestingly, some genetic disorders of iron metabolism and/or chronic inflammation often evolve in iron overload and recent evidences show for example the possibility of lowering brain iron accumulation with the membrane permeant chelators deferiprone in Friedreich ataxia (18-21).

However, the choice of iron chelators is critical. Normally, the chelation of excess iron give rise to more inactive complex, hence providing a useful method to prevent toxic effect of iron-overload diseases. In contrast, some chelators are able to enhance the production of ROS after complexation with $\mathrm{Fe}^{2+}$. These chelators may provoke interesting $\mathrm{Fe}^{2+}$ toxicity for cancer chemotherapy $(22,23)$. By rapidly depleting proliferating cancer cells of $\mathrm{Fe}^{2+}$, iron chelators can also inhibit the activity of iron who acts as coenzymes to essential step of DNA synthesis (24-26). In addition, $\mathrm{Fe}^{2+}$ depletion are known to affect the expression of molecules involved in cell cycle progression and growth, i.e. N-myc downstream regulated gene 1, cyclin D1, cyclin A and p21waf1 leading to G1/S arrest in the cell cycle (27-29). These effects combined with ROS generation, provide multiple mechanisms of action mediated by the $\mathrm{Fe}^{2+}$ chelation to inhibit tumor growth.

Curcumin is the major chemical component of turmeric, a dietary spice made from the root of the Curcuma longa L. and used extensively in traditional Indian medicine (30). Curcumin is a potent bioactive compound actively in study against cancer (31-33), atherosclerosis(34), steatohepatitis (35) and neurodegenerative diseases,such as Alzheimer's $(36,37)$ and Parkinson's disease $(38,39)$, as well as to promote wound healing (40-42). At the cell level, curcumin mechanisms of action are complex and multifactorial. We and others previously address its mode of action and confirm its hormetic nature (43-47). Indeed, at low concentration, curcumin carries an effective antioxidant activity whereas at higher concentration $(>20 \mu \mathrm{M})$ behave as a potent pro-oxidant (47). In the field of cancer, curcumin inhibits the proliferation of tumor cells in vitro and in vivo. It inhibits also cell invasion, arrests cancer cells at G2/M phase of the cell cycle, and induces autophagy. Furthermore, curcumin suppresses the activation of Akt, mTOR and P70S6K proteins $(46,48,49)$. Curcumin, therefore, is a potent tumor suppressor and simultaneously an inducer of autophagy. In case of failure, this sequence of events leads to apoptosis (44). All together, these data imply a fail-secure mechanism regulated by autophagy in the action of curcumin, suggesting a therapeutic potential for curcumin offering a novel strategy for the treatment of malignant cells (47). Curcumin modulates proteins of iron metabolism in cells and in tissues, and chemical structure suggests that curcumin has properties of an iron chelator (50-53). Indeed, the $\alpha, \beta$ unsaturated diketone moiety of curcumin can form chelates with transition metals (Figure 1) and especially with iron $(51,54)[51]$. Metal chelates of curcumin are mostly non-fluorescent, although absorption spectra shows significant changes that can be tracked for assessing efficient chelation. Metal chelates of curcumin of the type
1:1 and 1:2 have been reported for the ions $\mathrm{Cu}^{2+}, \mathrm{Fe}^{2+}, \mathrm{Mn}^{2+}$, $\mathrm{Pb}^{2+}$, and others (55). All these metals can play a role in amyloid aggregation, and curcumin is investigated as a chelating agent to act on Alzheimer pathogenesis (54). Since curcumin is also lipophilic and readily crosses membranes it may also chelate more metal ions intracellularly(56). Evidence shows that curcumin is more efficient when low amount of iron are present intracellularly (53). However, how curcumin binds to these metals was not investigated in details and neither the consequences of this interaction in terms of autophagy and cell death mechanisms.

In this context, curcumin may be effective in preventing chemically-induced liver damages, by decreasing liver toxicity in rats in the case of galatosamine or carbon tetrachloride intoxication (57) and also abolished carcinogenic effects of afflatoxin and/or nitrosodiethyamine $(58,59)$.

Here we demonstrate that curcumin do not change the amount of intracellular iron loaded but that it's chelating activity is crucial for inhibiting iron overload cytoxicity and further effects on liver cell line. These findings put curcumin as a powerful alternative candidate for the control of liver damages linked to intracellular iron overload. Moreover, we tested the capability of curcumin as powerful iron chelator to prevent tumor promotion in T51B and RL-34 cells. Together with the fact that curcumin binds to iron and prevent iron toxicity (60-62), we find that curcumin chelation act similarly as deferroxamine (29) by inhibiting tumor promotion.

\section{Results.}

Curcumin binds iron. Evidence for iron binding to curcumin in solution has been previously demonstrated using spectroscopic shift techniques $(54,63)$. The Figure 1 shows capability of curcumin to chelate divalents cations like $\mathrm{Fe}^{2+}$ directly (1a) or in conjunction with other ligands (1b). We used then, an alternative metal affinity chromatography method with handmade Fe-NTA columns. The Figure 2a shows the loading efficiency of curcumin from solution to the Fe-NTAagarose column. Curcumin binding was rapid and efficient, reaching up to $90-95 \%$ after incubation for 10 minutes on the iron-containing resin. It is well known that the diketone groups of curcumin likely interact with the Fe-NTA-resin in a similar fashion than the phosphate oxygens of the phosphopeptides, for which this iron affinity chromatography resin was developed (64). The data extracted from Figure 2 gave an affinity estimation around $\mu \mathrm{M}$, in agreement with the high affinity iron binding site of curcumin reported by Baum et al. (54). Comparable curcumin binding was not observed when Fe was substituted by $\mathrm{Ni}$ as the metal ion (64). A significant fraction of curcumin (based on absorbance signal at $435 \mathrm{~nm}$ ) was recovered from Fe-NTA-agarose upon addition of competitive iron chelators like deferoxamine (DFO) or EDTA (EGTA to a lesser extent)(Figure 2b). Vitamine E has much less efficiency of being an iron chelator. These data reinforced previous reports of curcumin specifically binding iron, and suggests may suggest a potential to reduce both uptake and toxicity of iron within cells. The curcumin absorbance spectra is modified by the presence of Fe-NTA. Effectively, 
bioRxiv preprint doi: https://doi.org/10.1101/722942; this version posted August 2, 2019. The copyright holder for this preprint (which was not certified by peer review) is the author/funder, who has granted bioRxiv a license to display the preprint in perpetuity. It is made available under aCC-BY-ND 4.0 International license.

a

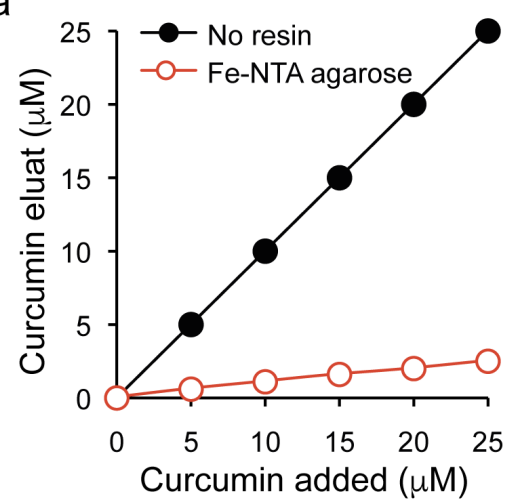

b

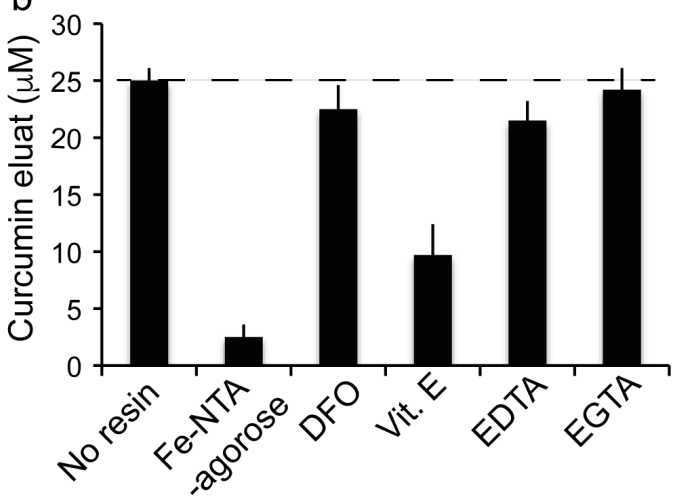

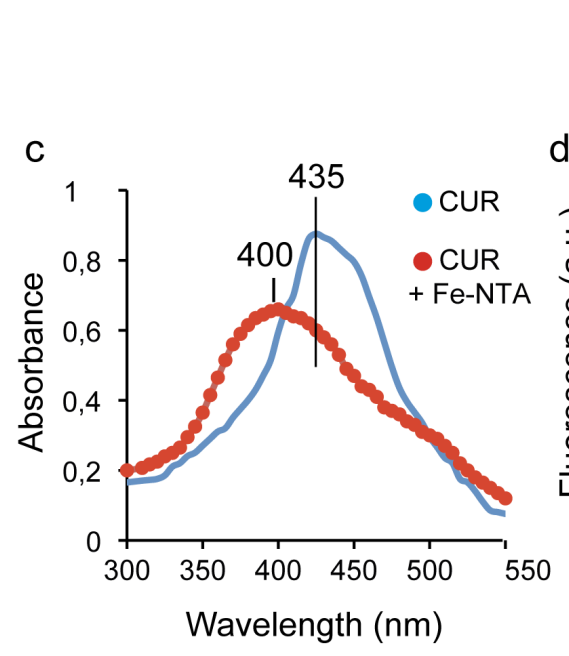

e

e
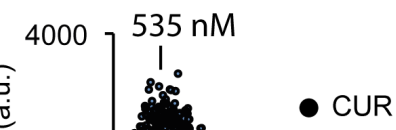

C
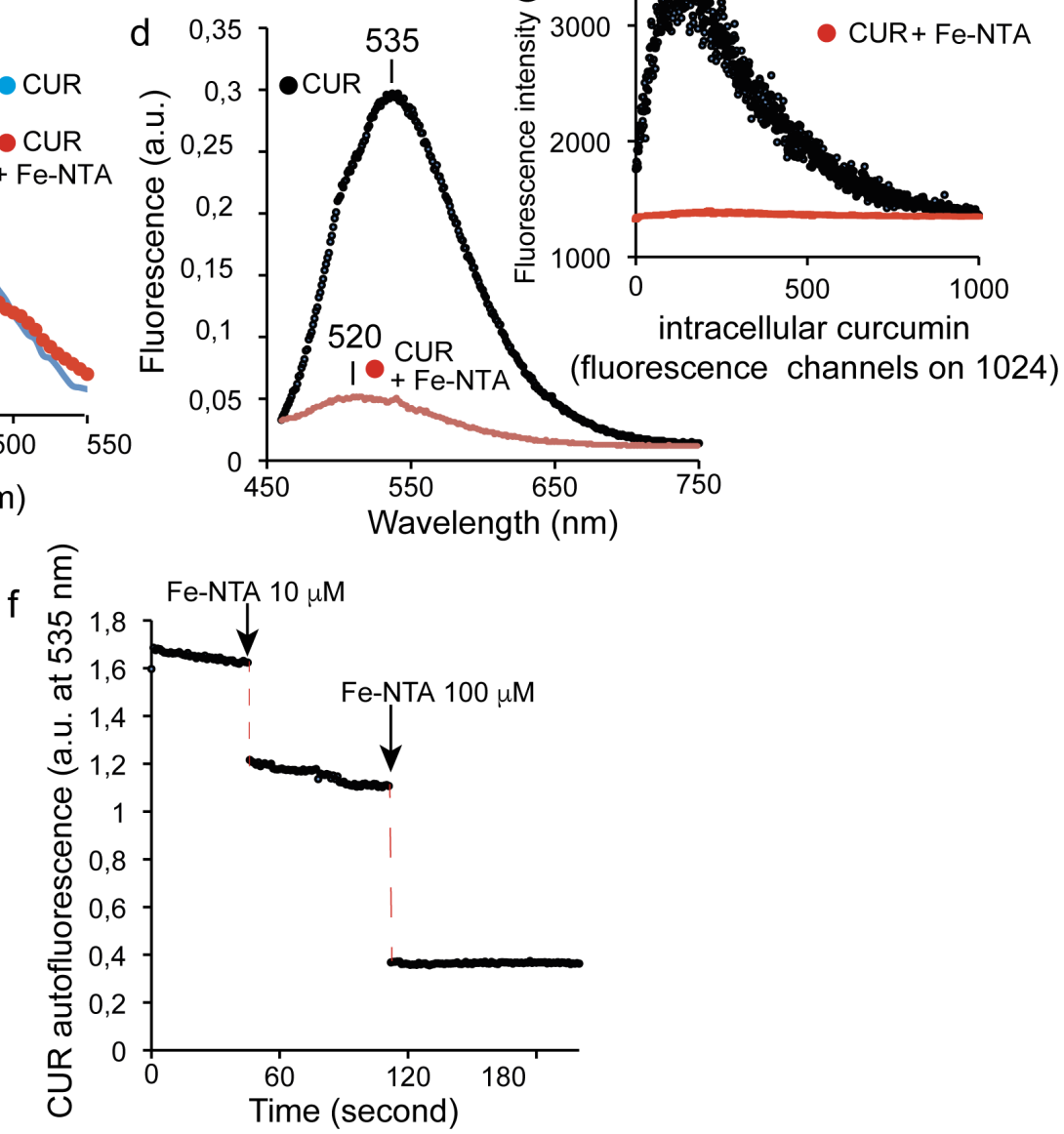

Fig. 2. Curcumin binds iron | a.Test of the removal of curcumin from solution by Fe-NTA resin. Increasing amounts of curcumin were incubated with Fe-NTA-Agarose (black circles) or without (open circles). The free curcumin remaining in solution after removal of the resin was determined by absorbance at $435 \mathrm{~nm}$ against calibration range $\mathbf{b}$. Inhibition of curcumin binding $(20 \mu \mathrm{M})$ incubated alone (no NTA resin) with iron resin (Fe-NTA agarose) or with iron resin pre-incubated with excess deferoxamine (DFO 250 $\mu \mathrm{M})$, excess vitamin $\mathrm{E}$ (Vit.E $1 \mathrm{mM})$, excess EGTA $(2 \mathrm{mM})$ or excess EDTA ( $2 \mathrm{mM})$. Unbound curcumin was determined as for panel a. Means \pm SE are presented from at least five independent determinations | c. Absorbance spectrum of Huh-7 cells treated by of $20 \mu \mathrm{M}$ curcumin for $6 \mathrm{~h}$ with (in red) or without (in blue) $100 \mu \mathrm{M}$ Fe-NTA loading for $24 \mathrm{~h}$ | d. Fluorescence emission spectra of Huh-7 cells treated by of $20 \mu \mathrm{M}$ curcumin for $6 \mathrm{~h}$ (same conditions as panel c)| e. Microspectrofluorimetry of Huh-7 cells treated as panel (c,d) and recording of the curcumin emission | f. Effect of Fe-NTA addition on the fluorescence recording of a curcumin solution ( $20 \mu \mathrm{M})$ at $535 \mathrm{~nm}$ realized in cuvette with an excitation at $435 \mathrm{~nm}$.

the absorbance of curcumin shifted from $435 \mathrm{~nm}$ to $400 \mathrm{~nm}$ for the complex when bound to iron (Figure 2c). Natural fluorescence behavior of free curcumin peaking at $535 \mathrm{~nm}$ is completely quenched when incubated with Fe-NTA, either in emission spectra or microspectrofluorimetry on cells (Figure 2d,e). Acellular experiments also demonstrate that Fe-NTA added to curcumin provoke an instantaneous, dose dependent quenching of curcumin fluorescence (Figure 2f).

Curcumin efficiently chelate $\mathrm{Fe}^{2+}$ but does not block iron uptake in Huh-7 cells. The dosage of intracellular iron shows 

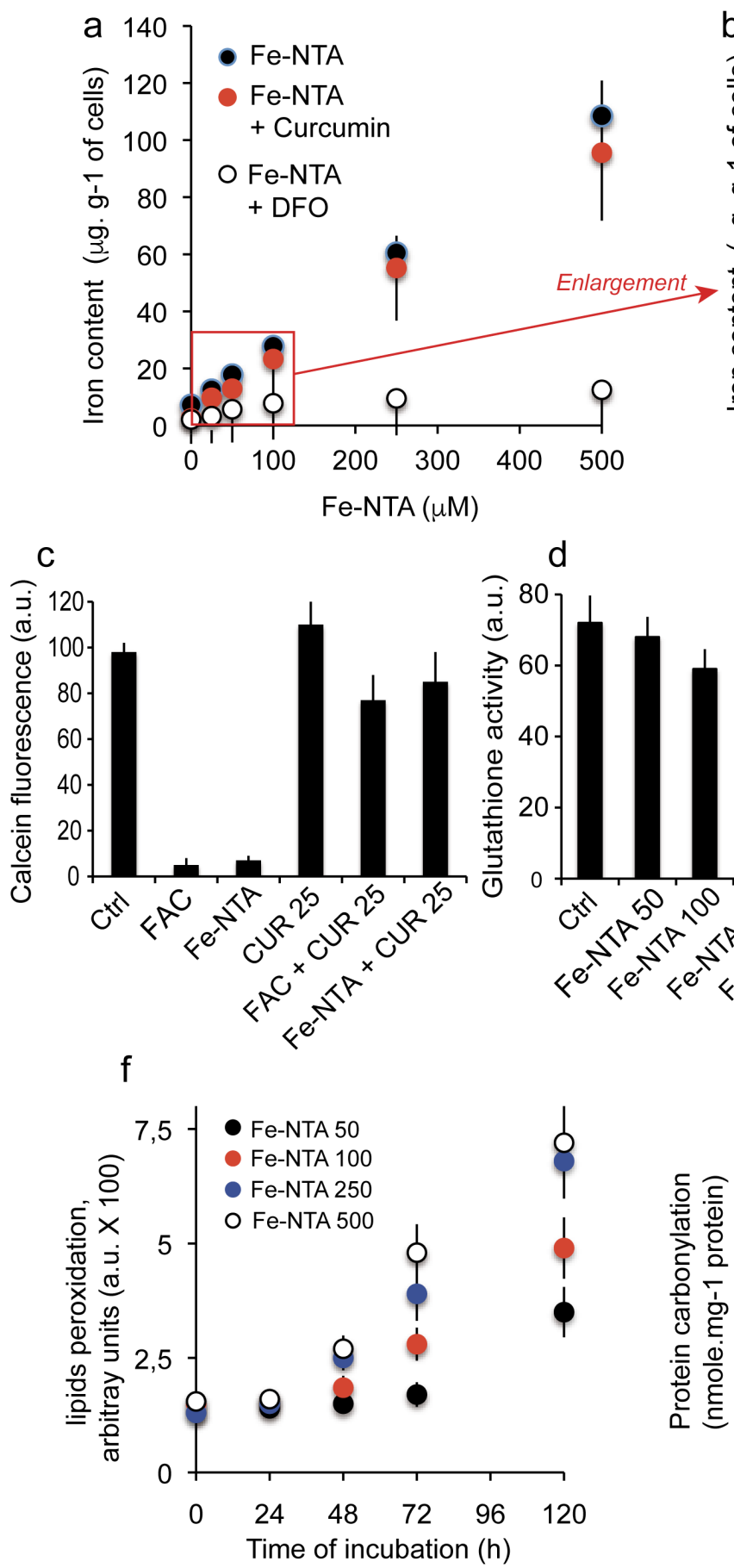
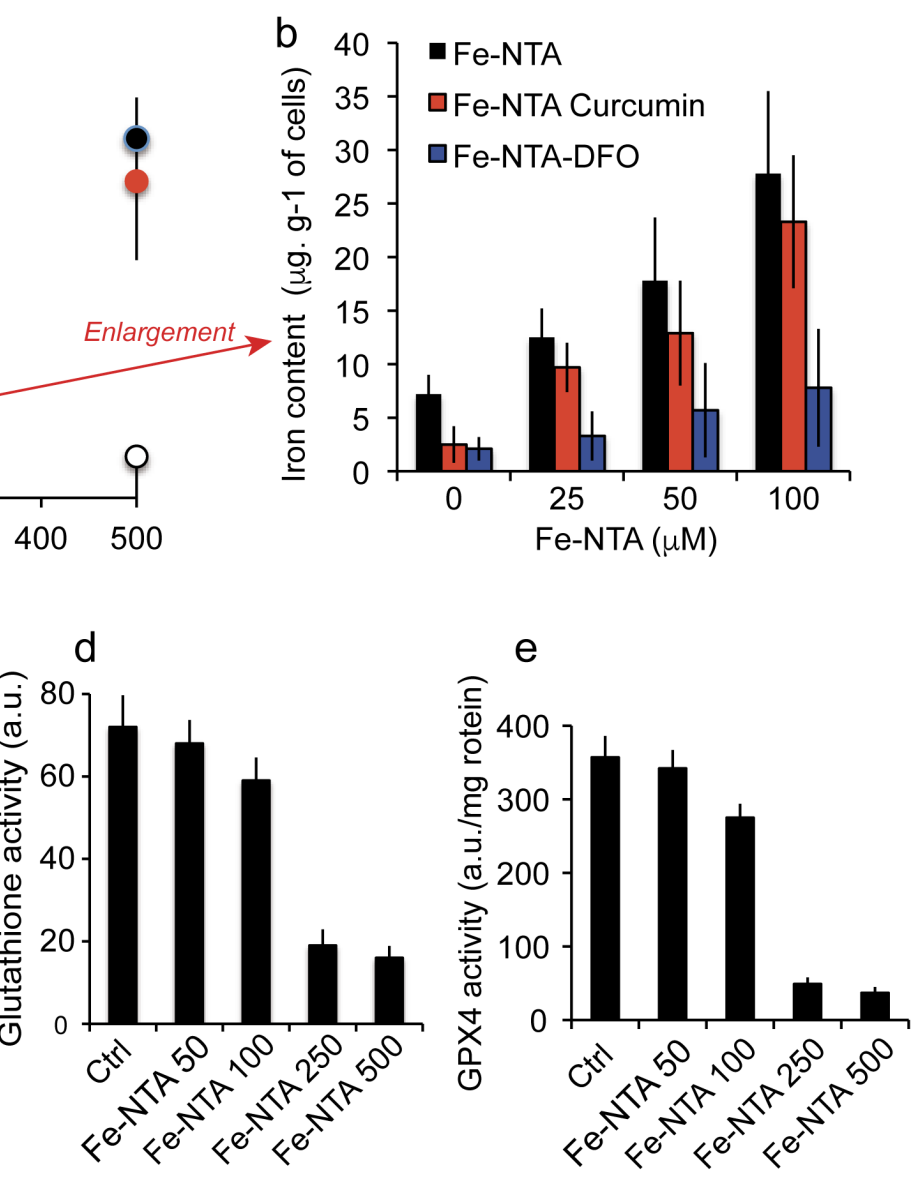

Fig. 3. Cellular iron content \& oxidative consequences | a. Fe-NTA cell loading $(0-500 \mu \mathrm{M})$ and measurements of the intracellular iron content in presence of DFO or Curcumin $(20 \mu \mathrm{M}) \mid$ b. Enlargement of the Fe-NTA cell loading in the lower range between 0 and $100 \mu \mathrm{M}$ in absence or presence of DFO (excess DFO, $250 \mu \mathrm{M})$ or curcumin $(20 \mu \mathrm{M}) \mid$ c. Cells were charged with calcein-AM and either FAC $(200 \mu \mathrm{M})$ or Fe-NTA $(100 \mu \mathrm{M})$ then compared at cells loaded with curcumin only $(20 \mu \mathrm{M})$. On last conditions cells are simultaneously treated with FAC and curcumin or Fe-NTA and curcumin. After $1 \mathrm{~h}$ the cells are rinsed with phosphate buffer saline (PBS) on ice and the calcein fluorescence measured ( \pm SD for 6 repeated experiments) | d. Effect of various treatment of Fe-NTA $(0$ to $500 \mu M)$ on the glutathion activity of Huh7 cells $\mid$ e. Same experiments as panel d. for assessing Glutathion peroxidase (GPX4) activity| $\mathbf{f}$. Effect of iron loading (as panel d) on lipid peroxidation as a function of time (0-120h) | $\mathbf{g}$. Effect of iron loading (as panel d) on protein carbonylation as a function of time (0-120h).

that iron chelation by curcumin do not alter cellular iron uptake whereas curcumin only slightly affect the total amount of intracellular iron (Figure 3a,b). The detected cellular iron is in the range of $28 \pm 10 \mu \mathrm{g} / \mathrm{g}$ of cells for a $48 \mathrm{~h}$ incubation with $100 \mu \mathrm{M}$ Fe-NTA whereas control cells contained $7,2 \pm 1,9 \mu \mathrm{g}$ iron/g of cells (Figure $3 \mathrm{~b}$ ). A pre-incubation with $\mathrm{DFO}$ and $\mathrm{CoCl}_{2}$ (data not shown) almost totally abolish iron content of the cells treated with $100 \mu \mathrm{M}$ Fe-NTA (Figure $3 b)$. Meaning that DFO and $\mathrm{CoCl} 2$ act mostly on the iron transport activity when curcumin acts intracellularly with an almost strict chelating activity (immobilization of the free intracellularly available $\mathrm{Fe}^{2+}$ ). Additive experiment with Cal- 


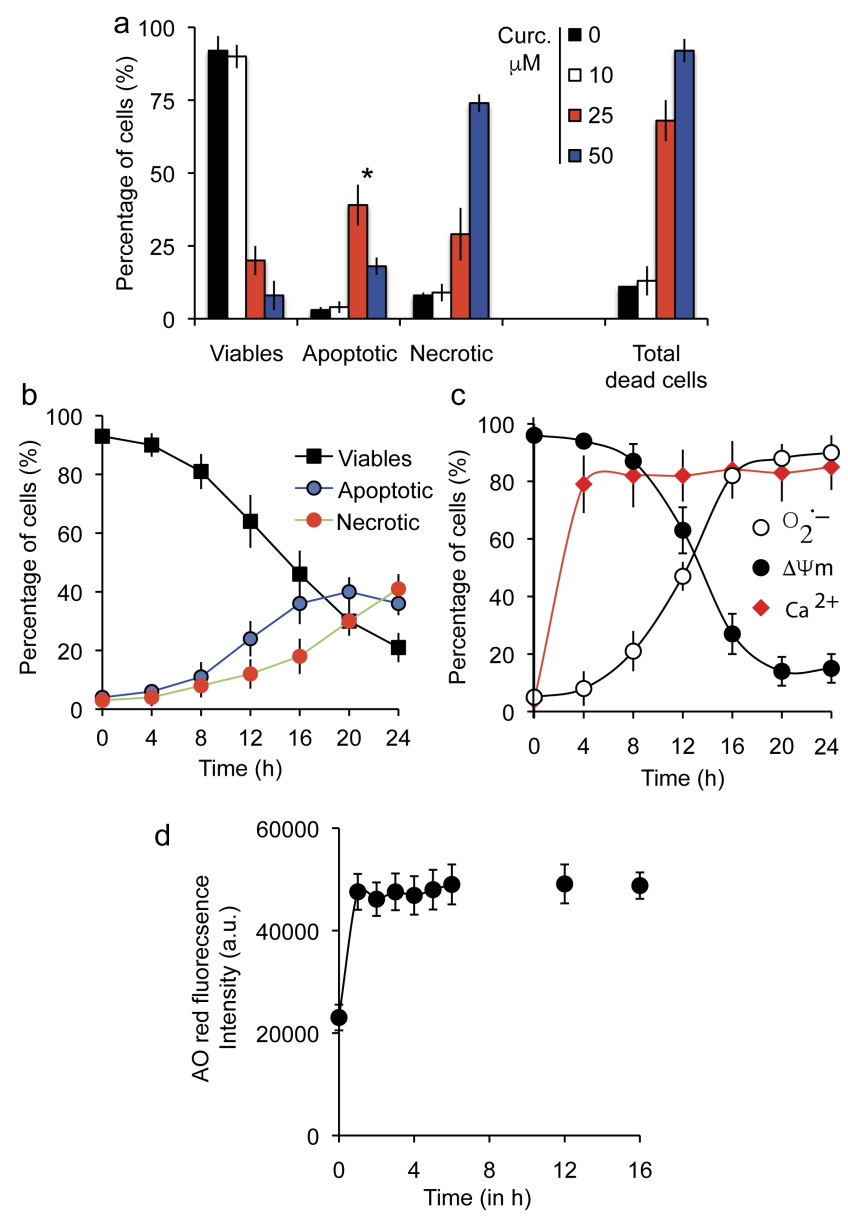

Fig. 4. Prototypic induction of cell death by curcumin | a. Flow cytometry analysis of Huh7 cells treated with various concentrations of curcumin $(0-50 \mu \mathrm{M}$ for 24 $\mathrm{h}$ incubation). YOPRO-1 / PI staining was used to analyze membrane permeability and discriminate three populations: viable (YOPRO-1- / PI-), apoptotic (YOPRO-1+ / $\mathrm{PI}$ - \& YO-PRO-1+/PI \pm ) and necrotic cells (YOPRO-1+/ $\mathrm{PI}+$ ) *The maximal amount of apoptotic cells is observed at $25 \mu \mathrm{M}$ of curcumin for $24 \mathrm{~h}$. Data are expressed as the mean \pm S.D. $(n=7) \mid$ b. Same experiment as panel a but plotted as a function of time from 0 to $24 \mathrm{~h}$ (curcumin $25 \mu \mathrm{M}$ ) | c. Metabolic measurements that are linked to the dying cells after 24 hours incubation at $25 \mu \mathrm{M}$ curcumin. Mitochondrial membrane potential with $\mathrm{DiOC}_{6}(3)$ fluorescence $(\Delta \Psi m$, black circles), superoxide anion generation tested with MitoSOX-green fluorescence $\left(\mathrm{O}_{2}{ }^{--}\right.$, empty circles) and calcium rise measured with Fluo 4-AM (intracellular calcium, red diamonds) | d. Acridine orange (AO) staining of cells during the 16 first hours after $25 \mu \mathrm{M}$ curcumin. Increased staining with rise of low $\mathrm{pH}$ vesicles (lysosomes) and fusion with bigger vesicles (autophagosomes) can be associated to autophagy induction.

cein, whose fluorescence quenching is strictly correlated with intracellular accumulation of iron, first demonstrates efficient quenching by Fe-NTA treatment and FAC (Figure 3c). Also, whatever the treatment method used, curcumin complexation with iron restore calcein fluorescence (Figure 3c).

Toxicity features associated to Fe-NTA loading. Increased loading of Fe-NTA (from 50 to $500 \mu \mathrm{M}$ ) is linearly related to the intracellular iron content but also associated (at doses $\geq 100 \mu \mathrm{M}$ ) with a significant reduction of the glutathion content (Figure 3d) and glutathion peroxidase activity (Figure $3 \mathrm{e})$. These events are associated with lipid peroxidation and protein carbonylation (Figure $3 \mathrm{f}, \mathrm{g}$ ). However, at the concentration of $100 \mu \mathrm{M}$ Fe-NTA for $48 \mathrm{~h}$ that we currently used in our work all these four parameters are discrete.
Cell death induction by curcumin. Huh-7 cells treated with curcumin at $25 \mu \mathrm{M}$ for $48 \mathrm{~h}$ and double-stained with YOPRO-1 versus PI exhibited different populations including viables cells (Y-/PI-), apoptotic cells (Y+/PI- or Y+/PI \pm , i.e. slightly positives) and cells undergoing necrosis (Y+/PI+++). The maximal apoptosis being reached at $25 \mu \mathrm{M}$ for $24 \mathrm{~h}$ since higher curcumin concentrations favor necrosis (Figure $4 \mathrm{a}$ ). It is interesting to notice that there is a huge difference betwwen $10 \mu \mathrm{M}$ and $25 \mu \mathrm{M}$ curcumin treatment and also that cumulated cell death (apoptosis + necrosis) reach 60 to $70 \%$ of death at $25 \mu \mathrm{M}$ for $24 \mathrm{~h}$. Clearly that is not the case with curcumin $10 \mu \mathrm{M}$ where the overall dead cells only reached $7 \%$ at $48 \mathrm{~h}$ ((Figure $4 \mathrm{~b}$, data not shown). It is not surprising, since curcumin binds to the ER, that the apoptotic processes are linked to calcium release from the endoplasmic reticulum (Figure 4c) during the first 4 hours of curcumin internalization. This calcium release influence directly the mitochondrial behavior, so, the mitochondrial membrane potential drop together with an increase production of superoxide anions probably associated with the mitochondrial permeability transition pore (MPTP) opening(Figure 4c). Following that $\Delta \Psi m$ drop, an important caspase- 8 and caspase $3 / 7$ activation occur as well as an NAD(P)H and NADH (fluorescent form) switch towards the reduced forms, NAD+ and $\mathrm{NADP}+$ (which are not fluorescent), then resulting in a drop of $\mathrm{NAD}(\mathrm{P}) \mathrm{H}$ that paralleled the $\Delta \Psi m$ decrease of fluorescence (Figure 5c). Clearly, if a comparison is made between the curves of apoptosis/necrosis and the physiological events underneath, their is a correlation between the disruption of the mitochondrial homeostasis (i.e. $\Delta \Psi m$ drop and $\mathrm{O}_{2}$ - production) and the early increase of apoptotic events followed by secondary necrosis (Figure 4b). The curcumin loading is quite rapid and associated with an immediate increase in red acridine orange fluorescence indicating an early induction of autophagic processes (Figure 4d). The correlation between AO red fluorescence and LC3-II occurrence has been previously described [44] and suggest that at certain concentrations, primary events induced by curcumin are linked to autophagy.

Iron chelation with curcumin resulted in a full inhibition of curcumin-induced autophagy and apoptosis. As demonstrated above, the cells treated with curcumin alone are undergoing autophagy (Figure 4d), apoptosis and necrotic death secondary to apoptosis (Figure 4a,b) with is characterized by a progressive loss of viability, a drop in $\Delta \Psi m$ associated with an increase of superoxide anions production but also the initiation of caspase- 8 together with caspase- 3 and caspase-9 (Figure 5c). Whereas, the iron-chelated with curcumin abolished completely the cell death inducing capacity of curcumin. Indeed, the expression of phosphatidyl serine at the cell membrane (late apoptotic and necrotic event) is abolished as well as the $\Delta \Psi m$ drop usually detected as an early event (Figure 5a). Superanions and hydrogen peroxide production are abolished (Figure 5b). Also, NAD $(\mathrm{P}) \mathrm{H}$ fluorescence and caspase- $3 / 7,-8$ and -9 are not activated anymore as curcumin alone do (Figure $5 \mathrm{c}$ ). Moreover, the AO red fluorescence linked to the increasing amount and big- 
bioRxiv preprint doi: https://doi.org/10.1101/722942; this version posted August 2, 2019. The copyright holder for this preprint (which was not certified by peer review) is the author/funder, who has granted bioRxiv a license to display the preprint in perpetuity. It is made available under aCC-BY-ND 4.0 International license.
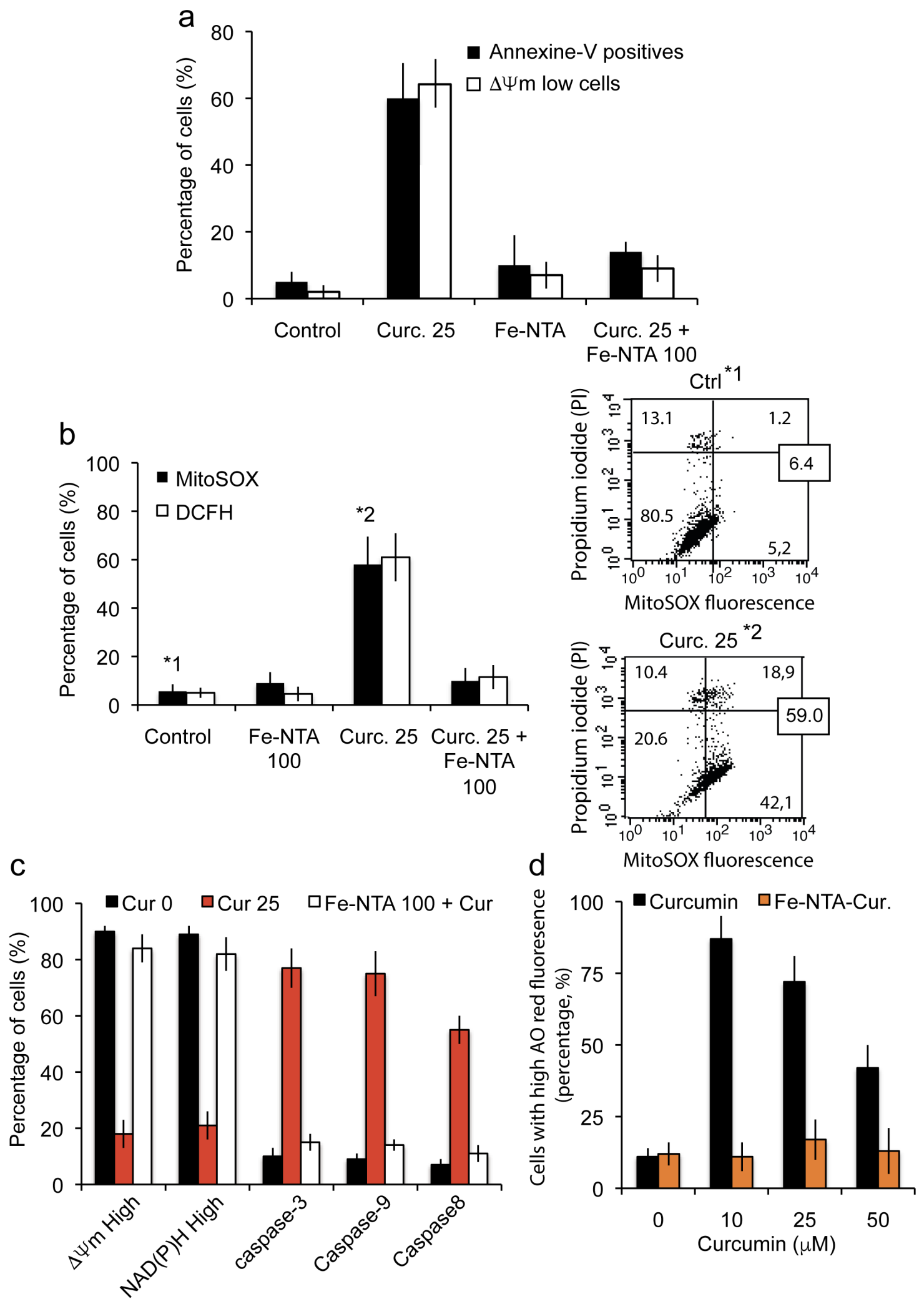

Fig. 5. Fe-NTA-curcumin complex abolish their own toxicity | a. Flow cytometry analysis of early and later events towards cell death (respectively drop of $\Delta \Psi m$ and PS exposure) when cells are treated for $24 \mathrm{~h}$ with $20 \mu \mathrm{M}$ curcumin or $100 \mu \mathrm{M}$ Fe-NTA alone or both products behaving as a chelate | b. Flow cytometry analysis of the consecutive events to the $\Delta \Psi m$ drop (panel a) that are the generation of superoxide anions (MitoSOX staining) and hydrogen peroxide production (DCFH-DA staining; each histogram is taken in 7 independent experiments and \pm SD is given). Control and $25 \mu \mathrm{M}$ curcumin (24h) conditions are illustrated respectively in $1^{*}$ and $2^{*}$ by biparametric plot together with the viability measurement (PI staining). The percentage of cells in each panel is given as a percentage of the whole population $\mid \mathbf{c}$. Metabolic analysis showing that treatment with both products restore control condition trend with respectively a large population of high $\Delta \Psi m$ (baseline) and $\mathrm{NAD}(\mathrm{P}) \mathrm{H}$ together with a low activation of initiation caspase (caspase-8) and executioner caspases (caspase-3 and caspase-9). Cells were treated with $25 \mu \mathrm{M}$ curcumin or $100 \mu \mathrm{M}$ Fe-NTA or both I d. Cells were treated for $24 \mathrm{~h}$ with curcumin or Fe-NTA, or both. Acridine orange (AO) staining is performed to investigate AO red fluorescence related to vesicle fluxes. Fe-NTA-curcumin complex abolish the increase caused by curcumin alone and run at baseline level. 
ger size of acidic vesicle linked to autophagy enhancement are maintained to control level (Figure 5d), whatever the curcumin concentration and up to $50 \mu \mathrm{M}$. Curcumin-induced autophagy is decreasing with increasing curcumin concentration because apoptosis and necrosis becoming predominant for treated cells (Figure 5d). It could be observed that below $10 \mu \mathrm{M}$, curcumin usually do not promote cell death but that autophagy is engaged. Above $10 \mu \mathrm{M}$, the amount and intensity of $\mathrm{AO}$ positives cells is decreasing as apoptosis and secondary necrosis take place.

Chelating activitity of curcumin on iron alleviates its tumor-promoting effect. To assess if curcumin, as a potent iron chelator, can also reduce or prevent the tumor-promoting effect of iron overload, we used T51B (rat liver epithelial cell) and RL-34 (rat liver epithelial diploid cell line). We used an impedancemetry control system (Xcelligence, ACEA) to follow and synchronize pre-culture before seeding on soft agar,and have decided to take the cells after $36 \mathrm{~h}$ when they are in the maximal proliferation phase (Figure 6c, black arrow). This has been done for both T51B and RL-34 cell lines. Previous studies show that iron act as a tumor promotor in T51B cells with a FAC induction associated to a low dose of N-Methyl-N'-nitro-N-Nitrosoguanidine (MNNG) generally acting by successives cycles of hepatotoxicity followed by regrowth and regeneration [71]. Acute iron overload is done with $250 \mu \mathrm{M} \mathrm{Fe}-\mathrm{NTA}$ or with FAC $+8 \mathrm{HQ}$ for 7 days in absence or presence of increasing amount of curcumin. The two cell lines exhibit a similar behavior and $50 \mu \mathrm{M}$ of curcumin is enough to efficiently counteract iron overload toxicity (Figure 6a,b). Whatever the iron overload protocol is, the induction of colonies takes over 12 weeks of repeated cycle of cells culture on soft agar, and the number of colonies is quite significant at 20 weeks of culture (over 120 colonies of 25.000 cells) (Figure 6d). By chelating iron, curcumin can control the number of colonies development who do not go over 5 colonies after 20 weeks of culture (Figure 6d) in both cell lines.

\section{Discussions.}

Curcumin to iron interactions. Previous experiments by cyclic voltammetry showed that curcumin binds metal ions and especially $\mathrm{Fe}^{2+}(63)$. The iron chelation activity of curcumin is related to it's chemical structure via the $\beta$-diketone group, a known bidentate chelator of $\mathrm{Fe}^{2+}$, similar to group found in simple analogous complex of Fe(II) and acetylacetonate. Based on the formation constant of $\mathrm{Fe}(\mathrm{II})$-curcumin of $10^{22} \mathrm{M}^{-1}$, it has been calculated that the $\mathrm{pFe}^{2+}(\mathrm{pM})$ of curcumin is of 16.6 ( at $\mathrm{pH} 7.4$ for $10 \mu \mathrm{M}$ curcumin and 1 $\left.\mu \mathrm{M} \mathrm{Fe}^{2+}\right)(63,65)$. This curcumin $\mathrm{pM}$ is not as high as other iron chelators already used in iron-overload treatment such as deferiprone $(\mathrm{pM}=20)$ and deferoxamine $(\mathrm{pM}=26)$ [73]. Curcumin $\mathrm{pM}$ could be compare favorably to the $\mathrm{pM}$ of the iron chelator nitrilotriacetic acid (NTA) that we use on the nickel column for curcumin extraction and many other iron chelators (Figure 2) and fit well with other iron chelating activity detected in vitro (65).
The methods used for loading iron to the cells allows us to go from an endogenous iron content of 7,2 $\pm 1,9 \mu \mathrm{g}$ iron/g of cells to a content of $28 \pm 10 \mu \mathrm{g} / \mathrm{g}$ of cells for a $48 \mathrm{~h}$ incubation with $100 \mu \mathrm{M}$ Fe-NTA (Figure3a). These results are not hindered by deleterious effects of iron as toxicity features become significative only above $100 \mu \mathrm{M}$ and longer time period. Iron toxicity is featured with lipid peroxidation and protein carbonylation (Figure $3 \mathrm{f}, \mathrm{g}$ ) also associated to a decrease in intracellular protection against ROS like glutathion activity decrease (Figure $3 \mathrm{~d}, \mathrm{e}$ ). The iron accumulation at higher FeNTA concentrations for $48 \mathrm{~h}$ leads to an intracellular accumulation of $60.5 \pm 13.2$ and $108.5 \pm 19.6 \mu \mathrm{g} / \mathrm{g}$ for Fe-NTA 250 $\mu \mathrm{M}$ and $500 \mu \mathrm{M}$, respectively. These conditions of loading go beyond the capacity of the endogenous Antioxidant defense system (ADS) with a clear depletion of the glutathion activity, overwhelmed by massive generation of ROS from cellular $\mathrm{Fe}^{2+}$ engaged in Fenton reaction / Haber-Weiss effect $(2,3)$. Despite curcumin clearly bond with iron, there is no significant reduction of the iron uptake within cells (Figure 3a) although we could consider a discrepancy due to transient interaction between curcumin and plasma membrane during primary penetration where it could interact with iron regulation system. So, from our data it results that curcumin binding to iron do not influence the intracellular iron amount in response to Fe-NTA treatment. We then, investigate if curcumin chelation with iron still feature an hormetic behavior or if it's activity is altered.

Curcumin cellular effects. We investigated the Huh7 profile response to curcumin as we previously done (44) and confirmed that curcumin exert an effect on endoplasmic reticulum which release calcium taken up by mitochondria via mitochondrial calcium uniport (MCU) who cause a drop in $\Delta \Psi m$ and a superoxide anions production, leading ultimately to an opening of the mitochondrial permeability transition pore (mPTP) (Figure 4c). These results fit with the further involvement of cathepsins and caspase- 8 activation leading to cytochrome $\mathrm{c}$ release and apoptosis previously described (44). This do not exclude also en early involvement of lysosomes as it is clear that curcumin in the $\mu \mathrm{M}$ range induce autophagic processes (Figure 4d)(44). This may explain some observations made by colleagues about the acceleration of neoplastic transformation when curcumin in the range of $10-20 \mu \mathrm{M}$ is added to iron $(29,66)$. It is possible that 10 $20 \mu \mathrm{M}$ of curcumin is more than enough to chelate all iron, and the remaining iron-free curcumin induce autophagy, enhancing neoplastic transformation $(44,47)$. Indeed, in neoplasic cells, autophagy constitute a coping mechanism with intracellular and environmental stress, thus favoring tumor progression (67).

\section{Curcumin-iron chelates abolish both curcumin effects and} iron cytotoxicity. When chelated with iron, curcumin loose capability to induce toxicity and cell death (Figure 5) which is in line with previous reports showing that iron attenuate curcumin cytotoxic effects in squamous cell carcinoma (68). That chelation is able to abolish late stage signals like outer exposure of phosphatidyl serine (Figure 5a) but also early 


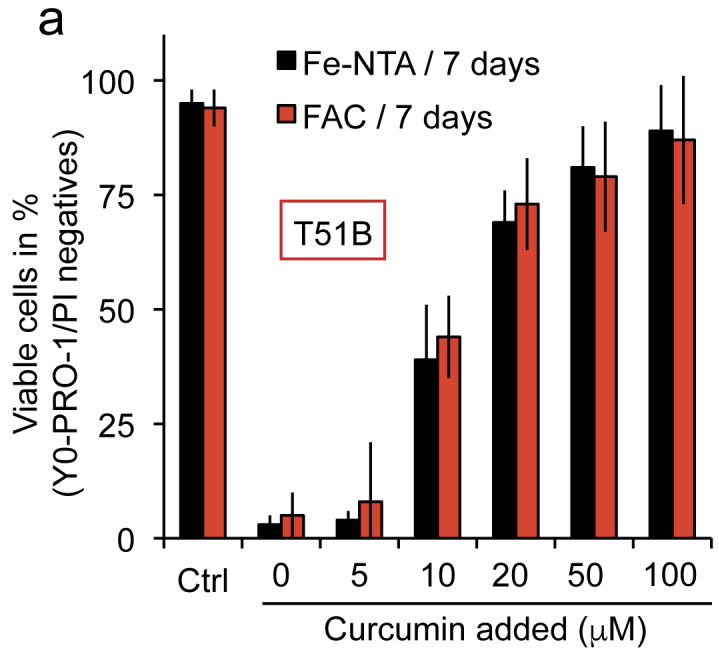

C

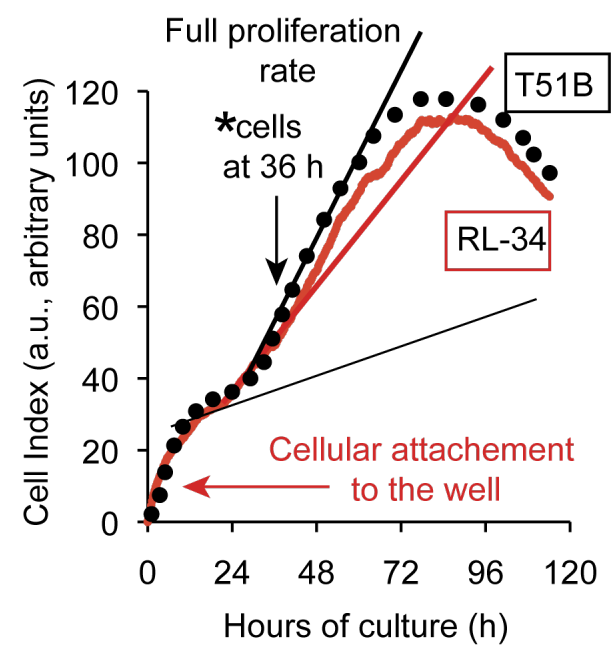

d b
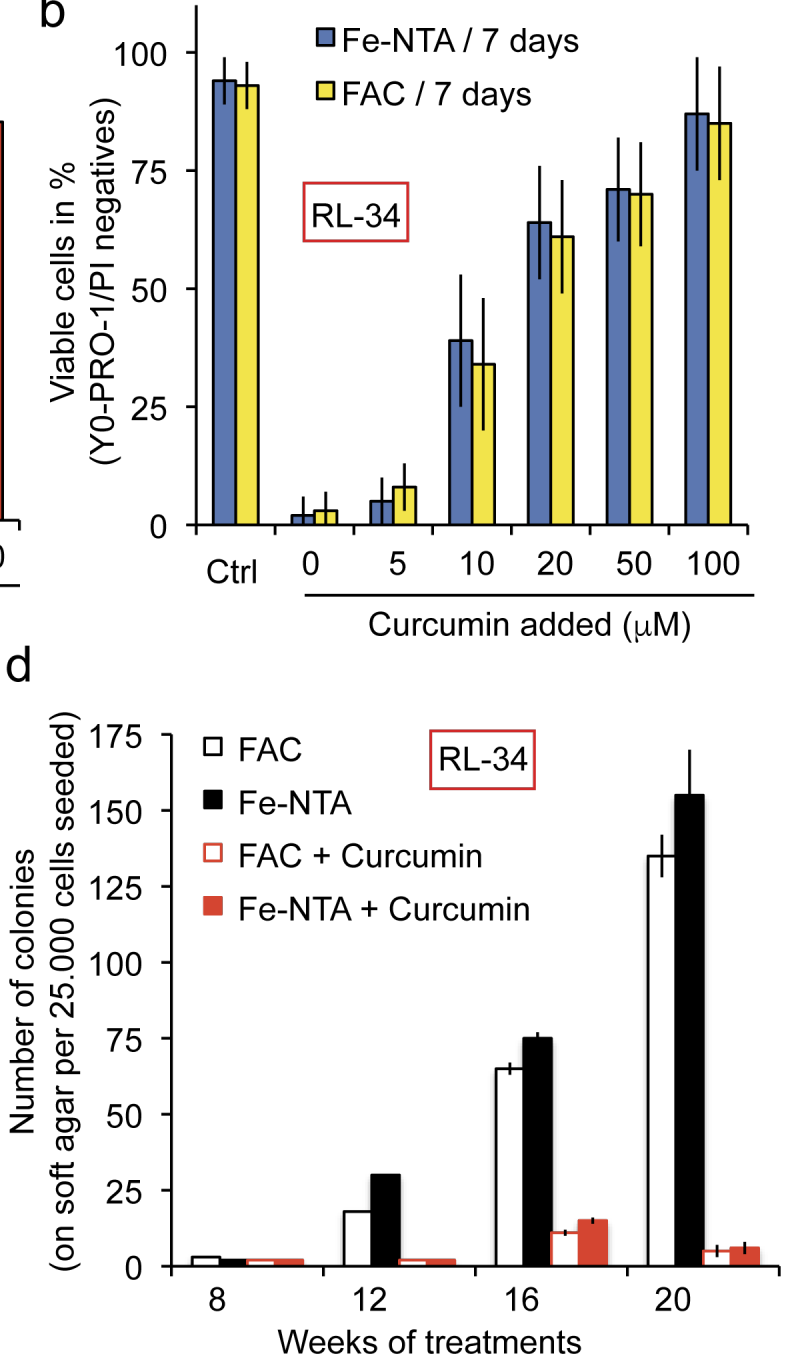

Fig. 6. Curcumin chelate with free iron alleviate the tumor promoting activity Fe-NTA or FAC | a. T51B cells are protected against free iron toxicity by curcumin in

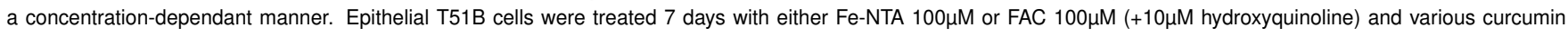
concentrations and then viability-tested by flow cytometry taking into account the dead cells (apoptotic, $\mathrm{A}$ and necrotic, $\mathrm{N}$ cells) to find the cellular viability $(100-(\mathrm{A}+\mathrm{N})=$ Viable cells in \%) | b. Same as in panel a but with RL-34 cells | c. The cells used in panel d experiment are first followed by impedencemetry (ACEA Xcelligence system) and taken at $36 \mathrm{~h}$ in their full proliferation phase after plating. Arrows (black) are setting the situation of the cells at $36 \mathrm{~h}$ and the Arrow (in red) along the early time on the curve pointed out the initial cell binding to the wells that in our case take almost $24 \mathrm{~h}$ before full proliferation take place. The curve is the mean value of 12 differents wells $\mid \mathbf{d}$. T51B cells plated at $2.10^{5}$ cells in $60 \mathrm{~mm}$ dish were treated with $0.5 \mathrm{mg} / \mathrm{ml}$ MNNG for 24 hours after plating and cultured either with $20 \mu \mathrm{M}$ curcumin or Fe-NTA $200 \mu \mathrm{M}$ (or FAC 250 $\mu \mathrm{M}$ with 8-hydroxyquinoline), or both. The number of soft agar experiments conducted was $\mathrm{n}=7$ and \pm SD were taken.

production of both hydrogen peroxides and superoxide anions from the mitochondrial compartment (Figure 5b). These results fit with other inhibition linked to cell death like the drop of mitochondrial potential, reduction of $\mathrm{NAD}(\mathrm{P}) \mathrm{H}$, activation of caspases 3/9/8 (Figure 5c). These results contrast with the ongoing hypothesis that combination of ions and ligands would produce a synergistic effect on cells (6971). A possible explanation would come from the fact that the central carbon has a labile hydrogen that is locked into the chelate and is truly unable to produce oxyradicals unless complete dissociation. According to these data, ketoenol function is more likely to drive the curcumin-induced autophagic process (Figure 5d). Another hypothesis to consider would be the modification of the global size and hindrance of the curcumin chelate compare to free curcumin. Soft agar tumorigenesis model allowed us to investigate for a longer period how RL-34 cells would evolve on iron-induced stress (with a MNNG starter) and curcumin treatment. As FAC or Fe-NTA treatment $(250 \mu \mathrm{M})$ are able to produce large number of colonies, $20 \mu \mathrm{M}$ curcumin is enough to abolish that growth (Figure 6d). Messner et al. recently evidenced this same response for $20 \mu \mathrm{M}$ curcumin but observe a tumor promotion for $10 \mu \mathrm{M}$ curcumin in the same settings (66). We hypothesize that curcumin at $10 \mu \mathrm{M}$ is already in excess compared to free iron, especially if curcumin can cycle the iron to transferrin and maintain it in redox inactive state (52). That excess is not enough to induce apoptosis and control tumorigenesis like $20 \mu \mathrm{M}$ does (Figure $6 \mathrm{~d}$ ), but enough to stimulate autophagic processes, hence, boosting tumorigenesis. On clinical cancer settings, we would need to address a specific curcumin payload, either partially chelating iron to reduce this tumor-promoting signal or increase payload enough to 
produce apoptosis and not boosting autophagy. On the opposite, iron-overload diseases management don't suffer that limitation, and while iron chelation is seeked, an extra autophagic signal could be valuable for patients at the tissue level, as well as anti-oxidative properties provided also by low concentration of curcumin.

\section{Methods.}

Chemicals and reagents. Curcumin, deferoxamine, 8hydroxyquinoline (8-HQ), ferric amonnium citrate (FAC), propidium iodide (PI), N-acetylcysteine (NAC) were obtained from Sigma-Aldrich Chemical Co. (St. Louis, MO, USA). Calcein-acetoxymethyl(Calcein-AM), 2,7Dichlorodihydrofluorescein diacetate (DCFH-DA),3,3'dihexyloxacarbocyanine iodide $\left[\mathrm{DiOC}_{6}(3)\right]$ and N-[4-[6[(acetyloxy)methoxy]-2,7-difluoro-3-oxo-3H-xanthen-9-yl]2-[2-[2-[bis[2-[(acetyloxy)methoxy]-2-oxoethyl]amino]-5methylphenoxy]ethoxy]phenyl]-N-[2-[(acetyloxy)methoxy]2-oxoethyl]-,(acetyloxy)methyl ester (Fluo-4 AM) were purchased from Molecular Probes (Invitrogen, Eugene, OR, USA). Agarose was obtained from Lonza (Walkersville, MD, USA. The 8-hydroxyquinoline is given together with FAC to enhance its internalization.

Cells. Human hepatoma-derived Huh-7 cells (RIKEN BioResource Center, Tsukuba, Japan) were grown in the presence of 5\% CO2 with Dulbecco's modified Eagle's medium (DMEM) containing high glucose (25 mM Sigma-Aldrich, St. Louis, MI) with $10 \%$ Fetal Bovine Serum (FBS, Hyclone, Logan, UT) completed with $1 \%$ penicillin-streptomycin, HEPES NaOH $1 \mathrm{mM}$, Na-pyruvate $1 \mathrm{mM}$ and $1 \%$ nonessential amino acids (MEAM, GIBCO). T51B cells (rat epithelial cells lines, non-neoplasic) are a model to study tumor promotion in vitro. They can be transformed to grow in soft agar by treatment with low amount of carcinogens and tumors promotors (72). RL-34 cells (rat liver epithelial-like cells, non-neoplastic from JCRB bank, japan) were maintained with the same medium than T51B cells.

Neoplastic transformation. T51B and RL-34 cell neoplastic transformation was realized as described by Messner et al.(66) and the formed colony on soft agar counted as a transformation index(72). We follow exactly previous transformation protocol with a single treatment of $24 \mathrm{~h}$ with $0.5 \mu \mathrm{g} / \mathrm{ml}$ $\mathrm{N}$-methyl-N'-nitrosoguanidine (MNNG) followed by continuous culture for 20 weeks either with FAC (+ 8-HQ) or FeNTA at $250 \mu \mathrm{M}$ with or without curcumin at $25 \mu \mathrm{M}$. MNNG is added at the start to participate to the initiation of the tumorigenesis. The culture media is renewed almost every 2-3 days and colony formation are tested every two weeks with a special care when becoming more important at 16, 18 and 20 weeks of culture.

Intracellular Iron dosage. Intracellular iron content of Huh7 cells given in micrograms of iron per grams of cells were determined after treatment with $100 \mu \mathrm{M} \mathrm{Fe}-\mathrm{NTA}$ or/and $100 \mu \mathrm{M}$ DFO for $24 \mathrm{~h} .150 \mathrm{~cm}^{2}$ cell culture were trypsinized and collected with lysate buffer (trichloroacetic acid $0,1 \mathrm{~g} / \mathrm{L}$, chlorhy- dric acid $0.774 \mathrm{M}$, Mercaptoacetic acid $30 \mathrm{mM}$ ) to respect a $100 \mathrm{mg}$ cells for $400 \mu \mathrm{L}$ buffer. Lysate are heated at $65^{\circ} \mathrm{C}$ overnight and centrifuged. Supernatants are then analyzed by flame emission spectrometry (Institut Claude Bernard, ICB, Paris) and compared to standards to determine iron content.

Microspectrofluorimetry. The UV-visible confocal laser microspectrofluorimeter prototype was built around a Zeiss UMSP80 UV epifluorescence microscope (Carl Zeiss, Inc., Oberkochen, Germany), optically coupled by UV reflecting mirrors to a Jobin-Yvon HR640 spectrograph (ISA, Longjumeau, France). The $351 \mathrm{~nm}$ UV line of an argon laser (model 2025; Spectra-Physics, Mountain View, CA) was used for either drug or fluorochrome excitation. The diameter of the laser beam is first enhanced through a doublelens beam expander in order to cover the entire numerical aperture of the microscope's optics. The laser beam is then deflected by the epi-illumination system (dichroic mirror or semireflecting glass) and focused on the sample through the microscope objective (X63 Zeiss Neofluar water-immersion objective; numerical aperture $=1.2$ ) on a circular spot $0.5 \mu \mathrm{m}$ in diameter. The excitation power is reduced to less than 0.1 $\mathrm{mW}$ by neutral optical density filters. The objective was immersed in the culture medium, and a circular area $0.8 \mu \mathrm{m}$ in diameter was selected at the sample level, by interposing a field diaphragm on the emission pathway of the microscope, to selectively collect the fluorescence signal from the nucleus or a specific cytoplasmic area. Confocal conditions are met when the image of this analysis field diaphragm through the microscope objective perfectly coincides with the focus of the laser beam on the sample. Under these conditions, the experimental spatial resolution, measured on calibrated latex beads $(2,0.6$, and $0.16 \mu \mathrm{m}$ in diameter) labeled with the fluorescent probe fluorescein, is $0.5 \mu \mathrm{m}$ for the directions X, Y, and Z. Finally the fluorescence spectra were recorded after spectrograph dispersion, in the 380-630 region on a 1024 diode-intensified optical multichannel analyzer (Princeton Instruments, Inc., Princeton, NJ) with a resolution of $0.25 \mathrm{~nm} /$ diode. Each fluorescence emission spectrum was collected from 1 to $10 \mathrm{~s}$. Data were stored and processed on an 80286 IBM PS/2 microcomputer using the Jobin-Yvon "Enhanced Prism" software. It should be noted that, in order to avoid any possible fluorescence from a plastic or glass support during analysis with near-UV excitation, cells were grown on quartz plates that were then placed on the microscope stage in 50-mm thermostated Petri dishes, filled with $5 \mathrm{ml}$ of phosphate-buffered saline. A uranyl glass bar was used as a fluorescence standard to control laser power and instrumental response and to enable quantitative comparison between spectra recorded on different days. Sample heating, photobleaching, and photo damage were assessed empirically and found to be negligible under our experimental conditions. In particular, cells always remained viable after repeated fluorescence determinations, as controlled by phase-contrast micros.

Iron affinity resin. Fe-NTA-Agarose was constructed from commercially available nickel NTA agarose (Qiagen, S.A., 
France). The Ni-NTA agarose was stripped with EDTA and recharged with iron as been described (64). Binding and pull down experiments were performed in $50 \%$ ethanol and assumed $100 \%$ replacement of $\mathrm{Ni}$ sites with $\mathrm{Fe}^{2+}$ (as warranted by manufacturer). For binding experiments, the indicated amounts of curcumin were incubated with or without Fe-NTA-Agarose in 50\% ethanol at room temperature (roughly $25 \mathrm{nmol}$ metal binding sites in $0.5 \mathrm{ml}$ total volume). After 10 minutes, the resin was removed by centrifugation, and aliquots of supernatants were diluted as needed (10 fold) to determine remaining curcumin in solution (absorbance at $435 \mathrm{~nm}$ ). Affinity estimations were based on the method of Scatchard, assuming free curcumin equal to the amount remaining in solution in the presence of Fe-NTA-agarose, and bound curcumin equal to the amount curcumin added minus the free measured at each concentration shown. The experiments were conducted exactly as described by Messner et al. (52).

Determination of lipid peroxidation and protein carbonylation.. We used a lipid peroxidation assay kit (Abcam ab118970) to detect malondialdehyde (MDA) present in samples. The free MDA generated during lipid peroxidation refers to the oxidative degradation of lipids reacting with Thiobarbituric Acid (TBA) to generate a MDA-TBA adduct. The absorbance of MDA-TBA adduct was measured at 532 $\mathrm{nm}$ for a sensitivity as low as $1 \mathrm{nmol} /$ well, and concentration calculated with provided standards. Protein carbonylation has been assayed using the Cayman's Protein Carbonyl Fluorometric Assay Kit in Huh-7 cell lysates.

Cell viability, mitochondrial membrane potential $(\Delta \Psi m)$, ROS and calcium levels . 2 millions Huh-7cells were seeded on 6-well plates and maintained with $25 \mu \mathrm{M}$ of curcumin for a given period of time ranging from 0 to $48 \mathrm{~h}$ depending on the experiments. After treatment, cells were detached, harvested, washed and then resuspended together with their supernatants in Phosphate Buffer Saline (PBS). Before flow cytometry, various staining were used : $\operatorname{DiOC}_{6}(3)$ was added at $40 \mathrm{nM}$ final concentration for $\Delta \Psi m$ determination, DCFH$\mathrm{DA}$ at $5 \mu \mathrm{M}$ for hydrogen peroxide detection, MitoSOX at 1 $\mu \mathrm{M}$ for superoxide anion detection. Most of the time a double staining is realized in order to simultaneously assess cell viability, with propidium iodide (PI; stock at $1 \mathrm{mg}^{-\mathrm{mL}^{-1}}$ )in the case of $\mathrm{DiOC}_{6}(3)$, DCFH-DA and Fluo4-AM and with 2 $\mu \mathrm{g} / \mathrm{ml}$ TO-PRO-3 iodide (stock at $1 \mathrm{mg} \cdot \mathrm{mL}^{-1}$ ) for MitoSOX. A supplemental double staining was used for the distinction between viable, apoptotic and necrotic cells with YOPRO-1 / PI in parallel with a Annexin-V / PI staining realized with the Annnexin-V-FITC when needed (Immunotech, Beckman-Coulter).All samples were measured and analyzed on a FACS Calibur $4 \mathrm{C}$ as previously described $(73,74)$.

Detection of intracellular GSH activity and Glutathion peroxidase assay. Huh-7 cell content of GSH was determined using $50 \mu \mathrm{M}$ monochlorobimane $(\mathrm{mBCl}$, Molecular Probes, Eugene, OR) in an incubation of $20 \mathrm{~min}$ at room temperature in the dark (74). Monochlorobimane was dissolved in
$100 \%$ ethanol to a stock concentration of $40 \mathrm{mM}$ and stored at $-20^{\circ} \mathrm{C}$ and special precautions were used to minimize the exposure to ambient light. To assess efficiency of $\mathrm{mBCl}$ for detection of intracellular GSH, Huh-7 were also incubated with N-ethylmaleimide (NEM, Sigma) as a control, a GSH depleting agent, which has been used previously to establish the specificity of $\mathrm{mBCl}$ for detection of GSH (75). Nethylmaleimide was prepared as a stock solution in $100 \%$ ethanol and was added to cell suspension at $100 \mathrm{mM}$ final concentration for $10 \mathrm{~min}$ at room temperature prior to addition of $\mathrm{mBCl}$. Monochlorobimane fluorescence was assessed using a UV laser with excitation wavelength at $360 \mathrm{~nm}$ and an emission at $585 \pm 42 \mathrm{~nm}$ (Fl-2) set on a FACS Aria (BectonDickinson, USA). For glutathion peroxidase (GPX4) activity determination we used a colorimetric assay from Abcam (ab102530) and follow manufacturer instructions. Data are expressed in enzymatic units per mg of protein.

Calcein quenching experiments. In order to measure calceinquenching, cells were loaded with $0.25 \mu \mathrm{g} / \mathrm{ml}$ calcein-1 AM in serum free media for 30 minutes at $37^{\circ} \mathrm{C}$, rinsed, and then treated (in triplicate) as specified in complete culture media for 2 hours. The cells were rinsed three times with PBS, and green fluorescence was measured by flow cytometry at $530 \pm$ $30 \mathrm{~nm}$.

Caspase activation \& fluorimetric assays. Isolated Huh-7 cells were washed and suspended in calcium-free buffer solution (140mM NaCl, $1.13 \mathrm{mM} \mathrm{MgCl}_{2}, 4.7 \mathrm{mM} \mathrm{KCl}, 10 \mathrm{mM}$ glucose, 0.1 M EDTA, and 10mM HEPES, pH 7.2). Cells were then loaded at room temperature for $30 \mathrm{~min}$ with fluorescent indicator-linked substrates for activated caspase-8 (10 $\mathrm{M}$ Z Z-IETD-R110; Molecular Probes), caspase-9 (10 $\mu \mathrm{M}$ ZLEHD-R110; Molecular Probes), or caspases 3/7 (Caspase3/7 Green ReadyProbes ${ }^{\mathrm{TM}}$ reagent with a DEVD sequence, Molecular Probes).

\section{ACKNOWLEDGEMENTS}

As this manuscript is made with ${ }^{A} T_{E} \mathrm{X}$ we thank the whole $T_{E} \mathrm{X}$ community and the work of Dr. Ricardo Henriques's lab for the initial available template.

\section{AUTHOR CONTRIBUTIONS}

These contributions follow the Contributor Roles Taxonomy guidelines: https://casrai.org/credit/.

Conceptualization: N/A; Data curation: P.X.P; Formal analysis: P.X.P, N.E.R, A.M; Funding acquisition: P.X.P; Investigation: N.E.R, A.M, A.S, G.N, F.S, P.X.P; Methodology: A.M, P.X.P; Project administration: P.X.P; Resources: F.S, P.X.P; Software: N/A; Supervision: P.X.P; Validation: P.X.P; Visualization: N/A; Writing - original draft: N.E.R, A.M, P.X.P ; Writing - review \& editing: All authors.

\section{COMPETING INTERESTS}

The authors declare no competing interests.

\section{Bibliography}

1. John W Eaton and Mingwei Qian. Molecular bases of cellular iron toxicity. Free radical biology \& medicine, 32(9):833-40, may 2002. ISSN 0891-5849.

2. M. Valko, H. Morris, and M. Cronin. Metals, Toxicity and Oxidative Stress. Current Medicinal Chemistry, 2005. ISSN 09298673. doi: 10.2174/0929867053764635.

3. Fritz Haber and Joseph Weiss. The catalytic decomposition of hydrogen peroxide by iron salts. Proceedings of the Royal Society of London. Series A - Mathematical and Physical Sciences, 1934. ISSN 2053-9169. doi: 10.1098/rspa.1934.0221.

4. P. Stål. Iron as a hepatotoxin., 1995. ISSN 02572753.

5. P Stál, R Hultcrantz, L Möller, and L C Eriksson. The effects of dietary iron on initiation and promotion in chemical hepatocarcinogenesis. Hepatology (Baltimore, Md.), 21(2):521-8, feb 1995. ISSN 0270-9139.

6. Hider R.C. and Hoffbrand A.V. The role of deferiprone in iron chelation. New England Journal of Medicine, 2018. ISSN 1533-4406. doi: 10.1056/NEJMra1800219. 
bioRxiv preprint doi: https://doi.org/10.1101/722942; this version posted August 2, 2019. The copyright holder for this preprint (which was not certified by peer review) is the author/funder, who has granted bioRxiv a license to display the preprint in perpetuity. It is made available under aCC-BY-ND 4.0 International license.

7. Zu D Liu and Robert C Hider. Design of clinically useful iron(III)-selective chelators. Medicinal research reviews, 22(1):26-64, jan 2002. ISSN 0198-6325.

8. D R Richardson and D B Lovejoy. Complexes of gallium(III) and other metal ions and their potential in the treatment of neoplasia. Expert opinion on investigational drugs, 9(6):125770, jun 2000. ISSN 1354-3784. doi: 10.1517/13543784.9.6.1257.

9. Danuta S Kalinowski and Des R Richardson. Future of toxicology-iron chelators and differing modes of action and toxicity: the changing face of iron chelation therapy. Chemical research in toxicology, 20(5):715-20, may 2007. ISSN 0893-228X. doi: 10.1021/tx700039c.

10. B Halliwell. The chemistry of oxygen radicals and other derived species. Free radicals in biology and medicine, 1989.

11. Brent R. Stockwell, José Pedro Friedmann Angeli, Hülya Bayir, Ashley I. Bush, Marcus Conrad, Scott J. Dixon, Simone Fulda, Sergio Gascón, Stavroula K. Hatzios, Valerian E. Kagan, Kay Noel, Xuejun Jiang, Andreas Linkermann, Maureen E. Murphy, Michael Overholtzer, Atsushi Oyagi, Gabriela C. Pagnussat, Jason Park, Qitao Ran, Craig S. Rosenfeld, Konstantin Salnikow, Daolin Tang, Frank M. Torti, Suzy V. Torti, Shinya Toyokuni, K.A. Woerpel, and Donna D. Zhang. Ferroptosis: A Regulated Cell Death Nexus Linking Metabolism, Redox Biology, and Disease. Cell, 171(2):273-285, oct 2017. ISSN 0092-8674. doi: 10.1016/J.CELL.2017.09.021.

12. Scott J. Dixon, Kathryn M. Lemberg, Michael R. Lamprecht, Rachid Skouta, Eleina M. Zaitsev, Caroline E. Gleason, Darpan N. Patel, Andras J. Bauer, Alexandra M. Cantley, Wan Seok Yang, Barclay Morrison, and Brent R. Stockwell. Ferroptosis: An Iron-Dependent Form of Nonapoptotic Cell Death. Cell, 149(5):1060-1072, may 2012. ISSN 0092-8674. doi: 10.1016/J.CELL.2012.03.042.

13. Samantha W. Alvarez, Vladislav O. Sviderskiy, Erdem M. Terzi, Thales Papagiannakopoulos, Andre L. Moreira, Sylvia Adams, David M. Sabatini, Kıvanç Birsoy, and Richard Possemato. NFS1 undergoes positive selection in lung tumours and protects cells from ferroptosis Nature, 551(7682):639-643, nov 2017. ISSN 0028-0836. doi: 10.1038/nature24637.

14. Abigail Weiland, Yamei Wang, Weihua Wu, Xi Lan, Xiaoning Han, Qian Li, and Jian Wang. Ferroptosis and Its Role in Diverse Brain Diseases. Molecular Neurobiology, 56(7):48804893, jul 2019. ISSN 0893-7648. doi: 10.1007/s12035-018-1403-3.

15. P. Dusek, E. Bahn, T. Litwin, K. Jabłonka-Salach, A. Łuciuk, T. Huelnhagen, V. I. Madai, M. A. Dieringer, E. Bulska, M. Knauth, T. Niendorf, J. Sobesky, F. Paul, S. A. Schneider, A. Czlonkowska, W. Brück, C. Wegner, and J. Wuerfel. Brain iron accumulation in Wilson disease: a <i>post mortem</i> 7 Tesla MRI - histopathological study. Neuropathology and Applied Neurobiology, 43(6):514-532, oct 2017. ISSN 03051846. doi: 10.1111/nan.12341.

16. Annita Kolnagou, Christina N Kontoghiorghe, and George J Kontoghiorghes. New targeted therapies and diagnostic methods for iron overload diseases. Front. Biosci, 10:1-20, 2018.

17. Kevin J. Barnham, Colin L. Masters, and Ashley I. Bush. Neurodegenerative diseases and oxidative stress. Nature Reviews Drug Discovery, 3(3):205-214, mar 2004. ISSN 14741776. doi: $10.1038 / \mathrm{nrd} 1330$.

18. A Wong, Patrizia Cavadini, Cinzia Gellera, Bo Lonnerdal, Franco Taroni, and Gino Cortopassi. The Friedreich's ataxia mutation confers cellular sensitivity to oxidant stress which is rescued by chelators of iron and calcium and inhibitors of apoptosis. Human Molecular Genetics, 8(3):425-430, mar 1999. ISSN 14602083. doi: 10.1093/hmg/8.3.425.

19. E Shinar and E A Rachmilewitz. Oxidative denaturation of red blood cells in thalassemia. Seminars in hematology, 27(1):70-82, jan 1990. ISSN 0037-1963.

20. R. Liane Ramirez, Jiang Qian, Paolo Santambrogio, Sonia Levi, and Arnulf H. Koeppen. Relation of Cytosolic Iron Excess to Cardiomyopathy of Friedreich's Ataxia. The American Journal of Cardiology, 110(12):1820-1827, dec 2012. ISSN 0002-9149. doi: 10.1016/J. AMJCARD.2012.08.018.

21. Nathalie Boddaert, Kim Hanh Le Quan Sang, Agnès Rötig, Anne Leroy-Willig, Serge Gallet, Francis Brunelle, Daniel Sidi, Jean-Christophe Thalabard, Arnold Munnich, and Z loav Cabantchik. Selective iron chelation in Friedreich ataxia: biologic and clinical implications. Blood, 110(1):401-8, jul 2007. ISSN 0006-4971. doi: 10.1182/blood-2006-12-065433.

22. Danuta S Kalinowski and Des R Richardson. The evolution of iron chelators for the treatment of iron overload disease and cancer. Pharmacological reviews, 57(4):547-83, dec 2005. ISSN 0031-6997. doi: 10.1124/pr.57.4.2.

23. Y. Yu, J. Wong, D. B. Lovejoy, D. S. Kalinowski, and D. R. Richardson. Chelators at the Cancer Coalface: Desferrioxamine to Triapine and Beyond. Clinical Cancer Research, 12 (23):6876-6883, dec 2006. ISSN 1078-0432. doi: 10.1158/1078-0432.CCR-06- 1954.

24. Matthias Kolberg, Kari R Strand, Pål Graff, and K Kristoffer Andersson. Structure, function, and mechanism of ribonucleotide reductases. Biochimica et Biophysica Acta (BBA) - Proteins and Proteomics, 1699(1-2):1-34, jun 2004. ISSN 1570-9639. doi: 10.1016/J.BBAPAP.2004.02.007.

25. Lars Thelander, Astrid Gräslund, and Margareta Thelander. Continual presence of oxygen and iron required for mammalian ribonucleotide reduction: Possible regulation mechanism. Biochemical and Biophysical Research Communications, 110(3):859-865, feb 1983. ISSN 0006-291X. doi: 10.1016/0006-291X(83)91040-9.

26. Lars Thelander and A Gräslund. Mechanism of inhibition of mammalian ribonucleotide reductase by the iron chelate of 1 -formylisoquinoline thiosemicarbazone. Destruction of the tyrosine free radical of the enzyme in an oxygen-requiring reaction. Journal of Biological Chemistry, 258(7):4063-4066, 1983.

27. Effie Nurtjahja-Tjendraputra, Dong Fu, Juanita M Phang, and Des R Richardson. Iron chelation regulates cyclin D1 expression via the proteasome: a link to iron deficiencymediated growth suppression. Blood, 109(9):4045-54, may 2007. ISSN 0006-4971. doi: 10.1182/blood-2006-10-047753.

28. J Gao and D R Richardson. The potential of iron chelators of the pyridoxal isonicotinoyl hydrazone class as effective antiproliferative agents, IV: The mechanisms involved in inhibiting cell-cycle progression. Blood, 98(3):842-50, aug 2001. ISSN 0006-4971. doi: 10.1182/blood.v98.3.842.

29. Donald J Messner and Kris V Kowdley. Neoplastic transformation of rat liver epithelial cells is enhanced by non-transferrin-bound iron. BMC Gastroenterology, 8(1):2, dec 2008. ISSN 1471-230X. doi: 10.1186/1471-230X-8-2.

30. Bharat B. Aggarwal, Chitra Sundaram, Nikita Malani, and Haruyo Ichikawa. CURCUMIN THE INDIAN SOLID GOLD. In The Molecular Targets and Therapeutic Uses of Curcumin in Health and Disease, volume 595, pages 1-75. Springer US, Boston, MA, 2007. doi:
10.1007/978-0-387-46401-5_1.

31. Arshad H Rahmani, Mohammad A Al Zohairy, Salah M Aly, and Masood A Khan. Curcumin: a potential candidate in prevention of cancer via modulation of molecular pathways. BioMed research international, 2014:761608, sep 2014. ISSN 2314-6141. doi: $10.1155 / 2014 / 761608$.

32. Preetha Anand, Sherin G. Thomas, Ajaikumar B. Kunnumakkara, Chitra Sundaram, Kuzhuvelil B. Harikumar, Bokyung Sung, Sheeja T. Tharakan, Krishna Misra, Indira K. Priyadarsini, Kallikat N. Rajasekharan, and Bharat B. Aggarwal. Biological activities of curcumin and its analogues (Congeners) made by man and Mother Nature. Biochemical Pharmacology, 76 (11):1590-1611, dec 2008. ISSN 0006-2952. doi: 10.1016/J.BCP.2008.08.008.

33. Subash C. Gupta, Sridevi Patchva, and Bharat B. Aggarwal. Therapeutic Roles of Curcumin: Lessons Learned from Clinical Trials. The AAPS Journal, 15(1):195-218, jan 2013. ISSN 1550-7416. doi: 10.1208/s12248-012-9432-8.

34. José L. Quiles, M. Dolores Mesa, César L. Ramírez-Tortosa, Concepción M. Aguilera, Maurizio Battino, Ángel Gil, and M. Carmen Ramírez-Tortosa. Curcuma longa extract supplementation reduces oxidative stress and attenuates aortic fatty streak development in rabbits. Arteriosclerosis, Thrombosis, and Vascular Biology, 22(7):1225-1231, jul 2002. ISSN 10795642. doi: 10.1161/01.ATV.0000020676.11586.F2.

35. M. Carmen Ramirez-Tortosa, César L. Ramirez-Tortosa, M. Dolores Mesa, Sergio Granados, Ángel Gil, and José L. Quiles. Curcumin ameliorates rabbits's steatohepatitis via respiratory chain, oxidative stress, and TNF- $\alpha$. Free Radical Biology and Medicine, 47(7): 924-931, oct 2009. ISSN 0891-5849. doi: 10.1016/J.FREERADBIOMED.2009.06.015.

36. Rameshwar Patil, Pallavi R. Gangalum, Shawn Wagner, Jose Portilla-Arias, Hui Ding, Arthur Rekechenetskiy, Bindu Konda, Satoshi Inoue, Keith L. Black, Julia Y. Ljubimova, and Eggehard Holler. Curcumin Targeted, Polymalic Acid-Based MRI Contrast Agent for the Detection of A $\beta$ Plaques in Alzheimer's Disease. Macromolecular Bioscience, 15(9):1212-1217, sep 2015. ISSN 16165187. doi: 10.1002/mabi.201500062.

37. Zun-Jing Liu, Zhong-Hao Li, Lei Liu, Wen-Xiong Tang, Yu Wang, Ming-Rui Dong, and Cheng Xiao. Curcumin Attenuates Beta-Amyloid-Induced Neuroinflammation via Activation of Peroxisome Proliferator-Activated Receptor-Gamma Function in a Rat Model of Alzheimer's Disease. Frontiers in Pharmacology, 7:261, aug 2016. ISSN 1663-9812. doi: 10.3389/fphar.2016.00261.

38. Rajeswara Babu Mythri, Balusamy Jagatha, Nityananda Pradhan, Julie Andersen, and M. M. Srinivas Bharath. Mitochondrial Complex I Inhibition in Parkinson's Disease: How Can Curcumin Protect Mitochondria? Antioxidants \& Redox Signaling, 9(3):399-408, mar 2007. ISSN 1523-0864. doi: 10.1089/ars.2006.1479.

39. R. B. Mythri and M. M. Srinivas Bharath. Curcumin: A Potential Neuroprotective Agent in Parkinson's Disease. Current Pharmaceutical Design, 18(1):91-99, jan 2012. ISSN 13816128. doi: 10.2174/138161212798918995.

40. Silvia Tejada, Azadeh Manayi, Maria Daglia, Seyed F. Nabavi, Antoni Sureda, Zohreh Hajheydari, Olga Gortzi, Hamidreza Pazoki-Toroudi, and Seyed M. Nabavi. Wound Healing Effects of Curcumin: A Short Review. Current Pharmaceutical Biotechnology, 17(11):10021007, 2016. ISSN 13892010. doi: 10.2174/1389201017666160721123109.

41. Bopaiah Cheppudira, Marcie Fowler, Laura McGhee, Angie Greer, Alberto Mares, Lawrence Petz, David Devore, Dayna R Loyd, and John L Clifford. Curcumin: a novel therapeutic for burn pain and wound healing. Expert Opinion on Investigational Drugs, 22(10):1295-1303, oct 2013. ISSN 1354-3784. doi: 10.1517/13543784.2013.825249.

42. Dania Akbik, Maliheh Ghadiri, Wojciech Chrzanowski, and Ramin Rohanizadeh. Curcumin as a wound healing agent. Life Sciences, 116(1):1-7, oct 2014. ISSN 0024-3205. doi: 10.1016/J.LFS.2014.08.016.

43. Ji Young Kim, Tae Jin Cho, Bok Hee Woo, Kyung Un Choi, Chang Hun Lee, Mi Heon Ryu, and Hae Ryoun Park. Curcumin-induced autophagy contributes to the decreased survival of oral cancer cells. Archives of Oral Biology, 57(8):1018-1025, aug 2012. ISSN 0003-9969. doi: 10.1016/J.ARCHORALBIO.2012.04.005.

44. A Moustapha, PA Pérétout, NE Rainey, F Sureau, M Geze, J-M Petit, E Dewailly, C Slomianny, and PX Petit. Curcumin induces crosstalk between autophagy and apoptosis mediated by calcium release from the endoplasmic reticulum, lysosomal destabilization and mitochondrial events. Cell Death Discovery, 1(1):15017, dec 2015. ISSN 2058-7716. doi: 10.1038/cddiscovery.2015.17.

45. Bin Li, Takashi Takeda, Kenji Tsuiji, Tze Fang Wong, Mari Tadakawa, Akiko Kondo, Satoru Nagase, and Nobuo Yaegashi. Curcumin induces cross-regulation between autophagy and apoptosis in uterine leiomyosarcoma cells. International journal of gynecological cancer : official journal of the International Gynecological Cancer Society, 23(5):803-8, jun 2013. ISSN 1525-1438. doi: 10.1097/IGC.0b013e31828c9581.

46. Shouyu Guo, Mingzhi Long, Xiuzhen Li, Shushu Zhu, Min Zhang, and Zhijian Yang. Curcumin activates autophagy and attenuates oxidative damage in EA.hy926 cells via the Akt/mTOR pathway. Molecular Medicine Reports, 13(3):2187-2193, mar 2016. ISSN 17913004. doi: 10.3892/mmr.2016.4796.

47. N Rainey, L Motte, B B Aggarwal, and P X Petit. Curcumin hormesis mediates a cross-talk between autophagy and cell death. Cell Death \& Disease, 6(12):e2003-e2003, dec 2015. ISSN 2041-4889. doi: 10.1038/cddis.2015.343.

48. GUANGMING ZHAO, XIAODONG HAN, SIWEN ZHENG, ZHEN LI, YANG SHA, JING $\mathrm{NI}$, ZHE SUN, SONG QIAO, and ZHIQI SONG. Curcumin induces autophagy, inhibits proliferation and invasion by downregulating AKT/mTOR signaling pathway in human melanoma cells. Oncology Reports, 35(2):1065-1074, feb 2016. ISSN 1021-335X. doi: 10.3892/or.2015.4413.

49. Feng Guan, Youming Ding, Yemin Zhang, Yu Zhou, Mingxin Li, and Changhua Wang. Curcumin Suppresses Proliferation and Migration of MDA-MB-231 Breast Cancer Cells through Autophagy-Dependent Akt Degradation. PLOS ONE, 11(1):e0146553, jan 2016. ISSN 1932-6203. doi: 10.1371/journal.pone.0146553.

50. Yan Jiao, John Wilkinson, E. Christine Pietsch, Joan L. Buss, Wei Wang, Roy Planalp, Frank M. Torti, and Suzy V. Torti. Iron chelation in the biological activity of curcumin. Free Radical Biology and Medicine, 40(7):1152-1160, apr 2006. ISSN 0891-5849. doi: 10.1016/ J.FREERADBIOMED.2005.11.003.

51. Yan Jiao, John Wilkinson, Xiumin Di, Wei Wang, Heather Hatcher, Nancy D Kock, Ralph D’Agostino, Mary Ann Knovich, Frank M Torti, and Suzy V Torti. Curcumin, a cancer chemo- 
bioRxiv preprint doi: https://doi.org/10.1101/722942; this version posted August 2, 2019. The copyright holder for this preprint (which was not certified by peer review) is the author/funder, who has granted bioRxiv a license to display the preprint in perpetuity. It is made available under aCC-BY-ND 4.0 International license.

preventive and chemotherapeutic agent, is a biologically active iron chelator. Blood, 113(2): 462-9, jan 2009. ISSN 1528-0020. doi: 10.1182/blood-2008-05-155952.

52. Donald J. Messner, Gowsala Sivam, and Kris V. Kowdley. Curcumin reduces the toxic effects of iron loading in rat liver epithelial cells. Liver International, 29(1):63-72, jan 2009. ISSN 14783223. doi: 10.1111/j.1478-3231.2008.01793.x.

53. Steven Minear, Allyson F O'Donnell, Anna Ballew, Guri Giaever, Corey Nislow, Tim Stearns, and Martha S Cyert. Curcumin inhibits growth of Saccharomyces cerevisiae through iron chelation. Eukaryotic cell, 10(11):1574-81, nov 2011. ISSN 1535-9786. doi: 10.1128/EC. 05163-11.

54. Larry Baum and Alex Ng. Curcumin interaction with copper and iron suggests one possible mechanism of action in Alzheimer's disease animal models. Journal of Alzheimer's Disease, 6(4):367-377, aug 2004. ISSN 18758908. doi: 10.3233/JAD-2004-6403.

55. Kavirayani Priyadarsini, Priyadarsini, and Kavirayani Indira. The Chemistry of Curcumin: From Extraction to Therapeutic Agent. Molecules, 19(12):20091-20112, dec 2014. ISSN 1420-3049. doi: 10.3390/molecules191220091.

56. Ewa Jaruga, Adam Sokal, Slawomir Chrul, and Grzegorz Bartosz. Apoptosis-Independent Alterations in Membrane Dynamics Induced by Curcumin. Experimental Cell Research, 245 (2):303-312, dec 1998. ISSN 0014-4827. doi: 10.1006/EXCR.1998.4225.

57. S.S Deshpande, V.S Lalitha, A.D Ingle, A.S Raste, S.G Gadre, and G.B Maru. Subchronic oral toxicity of turmeric and ethanolic turmeric extract in female mice and rats. Toxicology Letters, 95(3):183-193, may 1998. ISSN 0378-4274. doi: 10.1016/S0378-4274(98)00035-6.

58. K.B. Soni, M. Lahiri, P. Chackradeo, S.V. Bhide, and R. Kuttan. Protective effect of food additives on aflatoxin-induced mutagenicity and hepatocarcinogenicity. Cancer Letters, 115 (2):129-133, may 1997. ISSN 0304-3835. doi: 10.1016/S0304-3835(97)04710-1.

59. S.E. Chuang, M.L. Kuo, C.H. Hsu, C.R. Chen, J.K. Lin, G.M. Lai, C.Y. Hsieh, and A.L. Cheng. Curcumin-containing diet inhibits diethylnitrosamine-induced murine hepatocarcinogenesis. Carcinogenesis, 21(2):331-335, feb 2000. ISSN 14602180. doi: 10.1093/carcin/21.2.331.

60. Ann W. Hsing, Joseph K. McLaughlin, Jorgen H. Olsen, Lenc Mellemkjar, Sholom Wacholder, and Joseph F. Fraumeni. Cancer risk following primary hemochromatosis: A population-based cohort study in Denmark. International Journal of Cancer, 60(2):160162, jan 1995. ISSN 00207136. doi: 10.1002/ijc.2910600204.

61. Y Deugnier and B Turlin. Iron and hepatocellular carcinoma. Journal of gastroenterology and hepatology, 16(5):491-4, may 2001. ISSN 0815-9319.

62. Kris V. Kowdley. Iron, hemochromatosis, and hepatocellular carcinoma. Gastroenterology, 127(5):S79-S86, nov 2004. ISSN 00165085. doi: 10.1016/j.gastro.2004.09.019.

63. Marganta Bernabéé-Pineda, Maria Teresa Ramírez-Silva, Mario Alberto Romero-Romo, Enrique González-Vergara, and Alberto Rojas-Hernández. Spectrophotometric and electrochemical determination of the formation constants of the complexes Curcumin-Fe(III)-water and Curcumin-Fe(II)-water. Spectrochimica Acta Part A: Molecular and Biomolecular Spectroscopy, 60(5):1105-1113, apr 2004. ISSN 1386-1425. doi: 10.1016/S1386-1425(03) 00344-5.

64. Wei Zhou, B. Alex Merrick, Morteza G. Khaledi, and Kenneth B. Tomer. Detection and sequencing of phosphopeptides. Journal of the American Society for Mass Spectrometry, 11(4):273-282, apr 2000. ISSN 1044-0305. doi: 10.1016/S1044-0305(00)00100-8.

65. A E Martell and R M Smith. Critical stability constants.,(Plenum Press: New York). Critical stability constants. Plenum Press, New York., 1974.

66. Donald J. Messner, Todd Robinson, and Kris V. Kowdley. Curcumin and Turmeric Modulate the Tumor-Promoting Effects of Iron In Vitro. Nutrition and Cancer, 69(3):481-489, apr 2017. ISSN 0163-5581. doi: 10.1080/01635581.2017.1274407.

67. L. Galluzzi, F. Pietrocola, J. M. Bravo-San Pedro, R. K. Amaravadi, E. H. Baehrecke, F. Cecconi, P. Codogno, J. Debnath, D. A. Gewirtz, V. Karantza, A. Kimmelman, S. Kumar, B. Levine, M. C. Maiuri, S. J. Martin, J. Penninger, M. Piacentini, D. C. Rubinsztein H.-U. Simon, A. Simonsen, A. M. Thorburn, G. Velasco, K. M. Ryan, and G. Kroemer. Autophagy in malignant transformation and cancer progression. The EMBO Journal, 34(7): 856-880, apr 2015. ISSN 0261-4189. doi: 10.15252/embj.201490784.

68. Kensuke Nakano, Tohru Nakayachi, Eiji Yasumoto, Sufi Reza M D Morshed, Ken Hashimoto, Hirotaka Kikuchi, Hirofumi Nishikawa, Kanji Sugiyama, Osamu Amano, Masami Kawase, and Hiroshi Sakagami. Induction of apoptosis by beta-diketones in human tumor cells. Anticancer research, 24(2B):711-7, mar 2004. ISSN 0250-7005.

69. Katherine H. Thompson, Karin Böhmerle, Elena Polishchuk, Candice Martins, Philip Toleikis, Jeremy Tse, Violet Yuen, John H. McNeill, and Chris Orvig. Complementary inhibition of synoviocyte, smooth muscle cell or mouse lymphoma cell proliferation by a vanadyl curcumin complex compared to curcumin alone. Journal of Inorganic Biochemistry, 98(12): 2063-2070, dec 2004. ISSN 0162-0134. doi: 10.1016/J.JINORGBIO.2004.09.011.

70. S Dutta, A Murugkar, N Gandhe, and S Padhye. Enhanced antioxidant activities of metal conjugates of curcumin derivatives. Metal-based drugs, 8(4):183-8, 2001. ISSN 0793-0291. doi: 10.1155/MBD.2001.183.

71. Shouchun Zhang, Chao Tu, Xiongyong Wang, Zhen Yang, Junyong Zhang, Liping Lin, Jian Ding, and Zijian Guo. Novel Cytotoxic Copper(II) Complexes of 8-Aminoquinoline Derivatives: Crystal Structure and Different Reactivity towards Glutathione. European Journal of Inorganic Chemistry, 2004(20):4028-4035, oct 2004. ISSN 1434-1948. doi: 10.1002/ejic. 200400357

72. Ju-Seog Lee, Jeonghoon Heo, Louis Libbrecht, In-Sun Chu, Pal Kaposi-Novak, Diego F Calvisi, Arsen Mikaelyan, Lewis R Roberts, Anthony J Demetris, Zongtang Sun, Frederik Nevens, Tania Roskams, and Snorri S Thorgeirsson. A novel prognostic subtype of human hepatocellular carcinoma derived from hepatic progenitor cells. Nature Medicine, 12(4): 410-416, apr 2006. ISSN 1078-8956. doi: 10.1038/nm1377.

73. N Zamzami, P Marchetti, M Castedo, D Decaudin, A Macho, T Hirsch, S A Susin, P X Petit, B Mignotte, and G Kroemer. Sequential reduction of mitochondrial transmembrane potential and generation of reactive oxygen species in early programmed cell death. Journal of Experimental Medicine, 182(2):367-377, aug 1995. ISSN 0022-1007. doi: 10.1084/JEM. 182.2.367.

74. M C Gendron, N Schrantz, D Métivier, G Kroemer, Z Maciorowska, F Sureau, S Koester, and $\mathrm{P} X$ Petit. Oxidation of pyridine nucleotides during Fas- and ceramide-induced apoptosis in Jurkat cells: correlation with changes in mitochondria, glutathione depletion, intracellular acidification and caspase 3 activation. The Biochemical journal, 353(Pt 2):357-67, jan 2001. ISSN 0264-6021. doi: 10.1042/BJ3530357.

75. David W. Hedley and Sue Chow. Evaluation of methods for measuring cellular glutathione content using flow cytometry. Cytometry, 15(4):349-358, apr 1994. ISSN 0196-4763. doi: $10.1002 /$ cyto. 990150411 